\title{
The performance of Chinese and Brazilian exports to Latin America, 1994-2009
}

\author{
Marcos Tadeu Caputi Lélis, André Moreira Cunba and \\ Manuela Gomes de Lima
}

ABSTRACT

This article analyses the structure of Brazilian and Chinese exports to Latin American markets, for the purpose of evaluating the repercussions of China's emergence as a global power and major trading partner of the countries of the region. An estimation of several international trade and competitiveness indicators shows that Chinese exports, particularly manufactured goods, are displacing Brazilian products on the regional market; and this poses a potential threat to Brazil.

KEYWORDS

JEL CLASSIFICATION

AUTHORS
Exports, Brazil, China, Latin America, measurement, evaluation, trade statistics, economic indicators, competitiveness

$\mathrm{F} 14, \mathrm{O} 57, \mathrm{O} 54$

Marcos Tadeu Caputi Lélis, Professor at Universidade do Vale do Rio dos Sinos (unisinos) and Coordinator of the Business Intelligence Unit of the Brazilian Trade Promotion Agency (Apex-Brasil). mcaputi@uol.com.br

André Moreira Cunha, Professor at the Department of Economic Sciences of the Federal University of Rio Grande do Sul (ufrgs) and Research Fellow at the National Council for Scientific and Technological Development (CNPq). andre.cunha@ufrgs.br

Manuela Gomes de Lima, Analyst at the Business Intelligence Unit of the Brazilian Trade Promotion Agency (Apex-Brasil). manuela.lima@apexbrasil.com.br 


\section{I}

\section{Introduction}

In the first decade of the twenty-first century, China consolidated its position as a global economic power and the projection of its very wide-ranging influence. The six-monthly reports produced by the International Monetary Fund (IMF) and other multilateral agencies and research centres were already showing that Chinese growth, in conjunction with the expansion of the United States economy, accounted over half of the rate of growth of world income in the 2003-2008 cycle. ${ }^{1}$ The current crisis has not altered this situation. On the contrary, the vigorous performance of the Chinese economy was reaffirmed in 2009, when its gross domestic product (GDP) grew by $8.7 \%{ }^{2}$ and with its economy projected to grow at rates of $9 \%$ - and $10 \%$ over the next few years, while the world's mature economies remain difficulty, China will continue to climb the international ranking. ${ }^{3}$

Against this backdrop, various studies are being undertaken to evaluate the repercussions on Latin America

$\square$ The opinions expressed in this article are the authors' exclusive responsibility and do not necessarily coincide with the official position of the institutions to which they are affiliated.

${ }^{1}$ See http://www.imf.org/external/ns/cs.aspx ?id=29 (access in May 2010, "China Quarterly Update" published periodically by the World Bank (http://web.worldbank.org/WBSITE/EXTERNAL/COUNTRIES/ EASTASIAPACIFICEXT/CHINAEXTN/0,contentMDK:20652127 pagePK:141137 piPK:141127 theSitePK:318950,00.html, viewed in May 2010); The annual Trade and Development Report published by the United Nations Conference on Trade and Development (UNCTAD) and the Annual Report of the Bank for International Settlements (BIS), among other publications.

${ }^{2}$ In 1990, China's GDP represented $4.2 \%$ of the world total, measured in purchasing power parity (PPP) dollars. In 2009, the proportion had grown to $12.5 \%$.

${ }^{3}$ On the rise of China, see, among others, Goldman Sachs (2007); Bijian (2006); Kang (2007); Naughton (2007); Kurlantzick (2007); National Intelligence Council (2008). of China's rise to world power status. ${ }^{4}$ This article forms part of that line of research, with an analysis that focuses on the period subsequent to the world financial crisis. A number of indicators are constructed of the performance of Brazilian and Chinese exports in the region. The analysis starts from a Brazilian perspective in which the Latin American market, particularly South America, has been vital for absorbing Brazil's manufactured exports. It can clearly be seen that Chinese exports are advancing into the spaces previously occupied by Brazilian suppliers. The article's main hypothesis is that China will seek to maintain diversified destination markets, while gradually reducing its reliance on the industrialized countries, which have been hit harder by the global financial crisis. In the framework of a "new normality", emerging country markets, including Latin American ones, are likely to be more vigorously contested (Gross, 2009; Spence, 2009), and this could displace Brazilian manufactured exports still further. It is argued that exports are the key to keeping China's internationalization strategy active, and thus guarantee stability in the country's modernization path. ${ }^{5}$

Following this brief introduction, the article is divided into three sections. Section II reviews the performance of Chinese exports worldwide in recent years, while section III compares the performance of Chinese and Brazilian exports in Latin America and identifies potential sectors in which Chinese exports could render Brazil less competitive. Final comments are made in section IV.

\footnotetext{
${ }^{4}$ Castro (2008); CAF (2006); Devlin, Estevadeordal and RodríguezClare (2006); Lederman, Olarreaga and Perry (2008); ECLAC (2009). ${ }^{5}$ See Bijian (2006) and Kurlantzick (2007).
} 


\section{II \\ The performance of Chinese exports in world trade}

The first decade of the twenty-first century saw China become a member of the World Trade Organization (wTO) in 2001, as foreign trade and financial flows from that country increased sharply as a proportion of world totals (Naughton, 2007; Goldman Sachs, 2007; UNCTAD (2009; ECLAC, 2009; Sen, 2010). This section seeks to analyse a number of aspects of that involvement and recent changes. The analysis starts from two empirical findings relating to the period 1981-2009. Firstly, since mid-1999, Chinese GDP growth has surpassed the average for the reference period, without a deterioration in the contribution made by its net exports to GDP growth (see figure 1). ${ }^{6}$ This stands in contrast to the pattern of

${ }^{6}$ Net exports are defined as the balance between exports and imports of goods and non-factor services in local currency. The contribution previous years, when the acceleration in growth reduced the external sector's contribution to the country's overall economic performance. Secondly, as seen in figure 1, and particularly figure 2 , since 2007 there has been a pronounced contraction in the contribution made by exports to income growth. Gross fixed capital formation (GFCF) now seems to be driving Chinese growth. ${ }^{7}$

\footnotetext{
made by net exports to GDP growth represents the percentage directly contributed by that aggregate to the rate of income growth. Thus, a negative value would indicate a negative contribution to the GDP growth rate, whereas a positive value would represent a positive contribution. The source of the raw data is Euromonitor International (www.eromonitor.com).

${ }^{7}$ On the debate over the factors driving Chinese growth, see, for example, Prasad and Rajan (2006); Naughton (2007); Sen (2010); Felipe and others (2010).
}

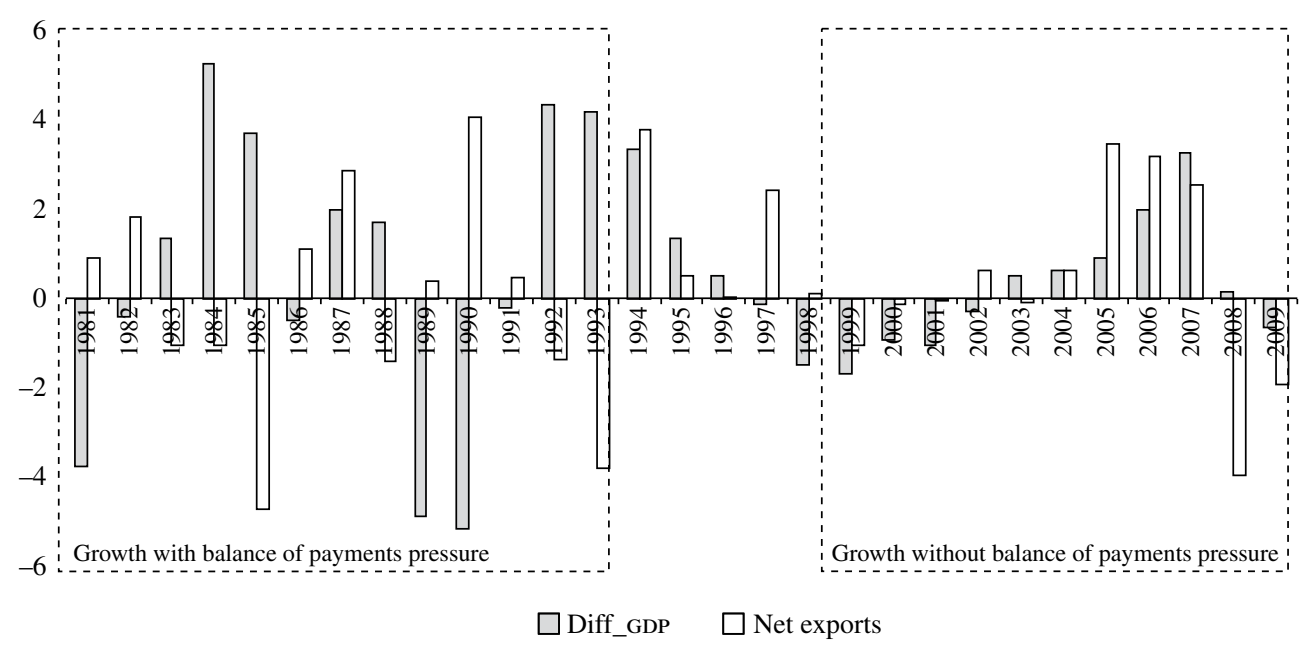

Source: Euromonitor International (www.eromonitor.com).

Note: Diff_GDP: Difference between average and annual GDP growth rates.

GDP: Gross domestic product. 
FIGURE 2

China: Contribution of gfcf and exports to gdp growth and their respective two-year moving averages, 1999-2009

(Percentages)

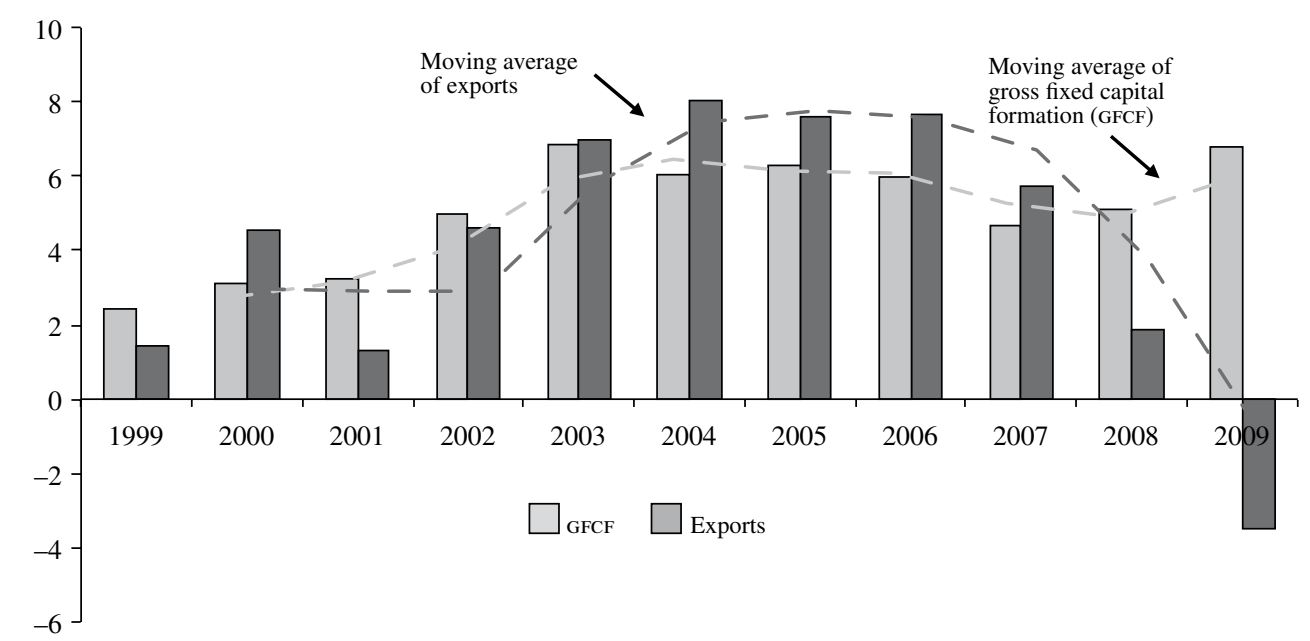

Source: Euromonitor International (www.euromonitor.com).

Nonetheless, from strategic standpoint, ${ }^{8}$ the external sector is a key factor in the dynamism of Chinese growth. ${ }^{9}$ Job creation and the generation of income and investments linked to the export sector are cited as key elements of that country's modernization process (Rodrik, 2006; Bijian, 2006; Naughton, 2007; Sen, 2010; Felipe and others, 2010). Although its larger net creditor position - stemming from a substantial accumulation of assets denominated in foreign currencies during recent years -

\footnotetext{
${ }^{8}$ See Yufan Hao, Wei and Dittmer (2009).

${ }^{9}$ Export growth is assumed to provide two basic benefits to an economy's development process (McCombie and Thirlwall, 1993; Thirlwall, 2003). The first of these relate to the effects on the process of expanding material prosperity in society and can be subdivided into two aspects: (i) exports are directly related to higher income in society; and (ii) export growth can create a virtuous circle of economic expansion based on the link between the production growth and productivity increase. The second benefit concerns the capacity to increase the country's income without putting pressure on the balance of payments. In other words, a continuous export growth dynamic makes it possible to finance the region's internal demand for imported goods through its own external sales, thereby facilitating rapid economic development in the country and reducing reliance on financing through the capital and financial account. In the last few years, the external financial constraint has not posed a major problem for China (Bijian, 2006), among other things because positive net exports contribute to achieving a net creditor external position.
}

has mitigated balance-of-payments sustainability risks, the deterioration of the trade account is permanently monitored by Chinese economic policymakers. In the years before the period of economic expansion in the first decade of the twenty-first century, productive modernization depended on access to foreign currency, guaranteed by both exports and borrowing, together with access to foreign investment (Wu, 2005).

As noted in the introduction, this article sees the quest for new export markets as crucial to China's development strategy. Consequently, despite the downtrend in China's net exports, its traditional markets, particularly the United States and Europe, are expected to continue to face economic difficulties in the next few years. In that context, and given Latin America's economic growth prospects for the next few years, this region is becoming a target for the expansion of China's external sales. Based on these premises, it is interesting to note the spread of China's trade before and after the world financial crisis, for which various indicators are calculated of the performance of China's international trade.

The first of these is China's trade intensity index (TII) with specific regions: United States, Asia, excluding Hong Kong (Special Administrative Region of China), Macau and Taiwan Province of China, the euro zone, 
the United Kingdom of Great Britain and Northern Ireland, ${ }^{10}$ Africa and Latin America, except for Brazil. ${ }^{11}$ This indicator is defined using the following structure:

$$
T I I_{j, i}=\frac{m_{i, j} / M_{i, w}}{x_{j, w} / X_{w, w}}
$$

Where: $m_{i, j}=$ Imports of country $i$ from country $j$; $M_{i, w}=$ Imports of country $i$ from the world; $x_{j, w}=$ Exports from country $j$ to the world; $X_{w, w}=$ Total world exports.

This index shows the extent to which exports from region $j$ to region $i$ are greater (or less) than expected,

\footnotetext{
10 The United Kingdom of Great Britain and Northern Ireland was included in the analysis because it does not belong to the euro zone, and because there has been a substantial movement in the trend of China's TII with that group.

${ }^{11}$ In this article, Latin America, excluding Brazil, is defined as comprising the following countries: Argentina, Bolivia (Plurinational State of), Chile, Colombia, Costa Rica, Cuba, Dominican Republic, Ecuador, El Salvador, Guatemala, Haiti, Honduras, Nicaragua, Panama, Paraguay, Peru, Uruguay and Venezuela (Bolivarian Republic of).
}

given the relative importance of region $j$ in international trade. A value above 1 indicates that the exports of $j$ to $i$ are greater than expected, given share of region $j$ in international purchases. ${ }^{12}$ Figure 3 shows the Chinese economy's TII with the regions mentioned between 1994 and 2008. ${ }^{13}$ The vertical dotted lines represent the difference between the minimum and maximum values of trade intensity recorded each year.

In general, China's trade intensity has increased with regions that had lower index at the start of the reference period, and there is a movement en bloc. At the same time, there is a slight reduction in the Chinese economy's TII with regions displaying a high index at the outset, thereby reducing the TII differential between regions. As a counterpart, the TII with the euro zone remained virtually stable. Nonetheless, non-European

\footnotetext{
${ }^{12}$ For further details see Hoekman, Mattoo and English (2002).

${ }^{13}$ Figure 3 uses data from the United Nations Commodity Trade Statistics Database (COMTRADE). As consolidated data for 2009 were not available, that year is excluded. This also applies to other information obtained from this source.
}

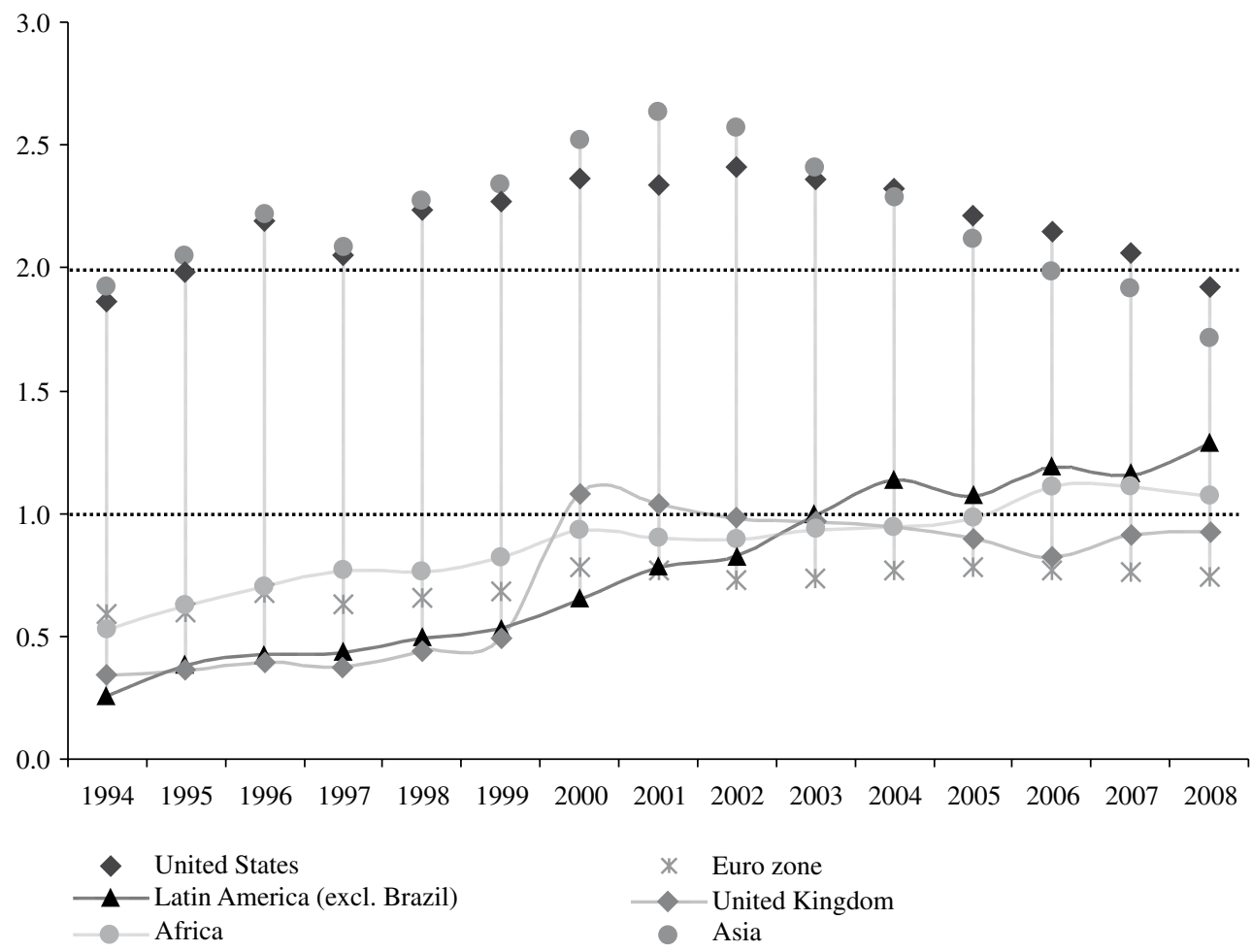

Source: United Nations Commodity Trade Database (COMTRADE). 
Union countries face well-known difficulties in increasing their trade intensity with that bloc, since that indicator is a relative measure of the intensity of exports from one region to another. Consequently, given the trade intensity within the bloc and the dynamic of openness to new markets for Chinese exports, the index ultimately remains constant. Nonetheless, the proportion of imports from China in the euro zone's total global purchases grew in absolute terms from $1.9 \%$ in 1994 to $6.3 \%$ in 2008. Despite the increased share of Chinese products in the euro zone's external purchases, the equivalent proportion grew more strongly in other regions, specifically in the United Kingdom, Africa and Latin America. Accordingly, the movements of those three regions are highlighted in figure 3.

Table 1 shows details of the deconcentration dynamic of China's export destinations, which to some extent could be discerned in the TII and indicated in figure $3 .{ }^{14}$ For that purpose the concentration ratio (CR) is used, which represents the share of the main trade partners in China's total exports. The value of $\mathrm{CR}(1)$ represents the share of China's exports sent to its main trading partner, while $\mathrm{CR}(2)$ represents the same indicator for the two leading partners, and so on.

The CR(15) index shows a sharp deconcentration in China's export destinations, with this trend intensifying after 1999, defined above as "Growth without balance of payments pressure". The deconcentration dynamic seems to have been provided mainly by the movement recorded within $\mathrm{CR}(2)$. Moreover, despite the increasing intensity of China's trade with the African continent and with Latin America, no country from those regions is included in the 15 main destinations for China's exports. This shows that the growth in China's trade intensity with Latin America and Africa occurred without causing major alterations in its preferential export destinations. In other words, China's external sales are consolidating in its main destinations, while gaining new positions in international trade at the same time.

This demonstrates the exceptional capacity of the Chinese economy to expand its export supply, given the size of its workforce and rate of growth of his productive base. ${ }^{15}$ Figure 4 shows that these movements occurred

\footnotetext{
14 The reader is reminded that China's trade with Hong Kong (Special Administrative Region of China), Macao and Taiwan Province of China is excluded.

${ }^{15}$ Deutsche Bank data estimate the average annual growth of China's investments at $12 \%$ between 1990 and 2009, and $14.5 \%$ per year between 2001 and 2009. Industrial production also grew by an average of $10 \%$ per year over the last 20 years (http://www.dbresearch.de, viewed in May 2010).
}

TABLE 1

China: Concentration index (cr) 1995, 1999, 2004, 2008 and 2009 (Percentages)

\begin{tabular}{|c|c|c|c|c|c|}
\hline \multicolumn{6}{|c|}{ China in the world } \\
\hline & 1995 & 1999 & 2004 & 2008 & 2009 \\
\hline $\mathrm{CR}(1)$ & 25.2 & 26.5 & 25.4 & 20.4 & 21.3 \\
\hline $\mathrm{CR}(2)$ & 47.1 & 47.0 & 40.3 & 29.8 & 30.7 \\
\hline $\mathrm{CR}(3)$ & 53.1 & 52.0 & 46.0 & 35.7 & 35.9 \\
\hline $\mathrm{CR}(4)$ & 58.1 & 56.9 & 50.8 & 40.5 & 40.7 \\
\hline $\mathrm{CR}(5)$ & 61.2 & 60.3 & 54.5 & 44.2 & 44.2 \\
\hline $\mathrm{CR}(10)$ & 72.8 & 72.5 & 66.8 & 57.1 & 57.1 \\
\hline $\mathrm{CR}(15)$ & 79.9 & 79.1 & 75.1 & 66.5 & 66.4 \\
\hline \multicolumn{6}{|c|}{ Main destinations - rank } \\
\hline United States & 2 & 1 & 1 & 1 & 1 \\
\hline Japan & 1 & 2 & 2 & 2 & 2 \\
\hline Republic of Korea & 3 & 3 & 3 & 3 & 3 \\
\hline Germany & 4 & 4 & 4 & 4 & 4 \\
\hline Netherlands & 6 & 5 & 5 & 5 & 5 \\
\hline England & 8 & 6 & 6 & 6 & 6 \\
\hline Singapore & 5 & 7 & 8 & 8 & 7 \\
\hline India & 23 & 21 & 17 & 9 & 8 \\
\hline France & 10 & 9 & 9 & 13 & 9 \\
\hline Australia & 13 & 11 & 12 & 14 & 10 \\
\hline Taiwan Province of China & 7 & 8 & 7 & 11 & 11 \\
\hline Italy & 9 & 10 & 10 & 10 & 12 \\
\hline Malaysia & 16 & 16 & 14 & 16 & 13 \\
\hline United Arab Emirates & 17 & 18 & 15 & 12 & 14 \\
\hline Canada & 14 & 12 & 13 & 15 & 15 \\
\hline
\end{tabular}

Source: Global Trade Information Services (GTIS).

without causing China's exports to become more sectorally concentrated. The index of the sectoral concentration of exports used is the Herfindahl-Hirschman index (HHI), which is defined as follows ${ }^{16}$ :

$$
H H I_{j}=\sum_{k=1}^{n}\left(\frac{x_{j, k}}{X_{j, w}} \times 100\right)^{2}
$$

Where: $x_{j, k}=$ Exports of sector $k$ by country $j ; X_{j, w}=$ Worldwide exports from country $j$.

On the scale of this indicator, a result below 1,000 means a low concentration, whereas an HHI between 1,000 and 1,800 reflects moderate concentration, and a

\footnotetext{
16 The indicator was calculated on the basis of the sectors defined by the National Classification of Economic Activities (CNAE), at the two-digit level. In the 1990s, the CNAE was developed by the Brazilian Institute of Geography and Statistics (IBGE) in conjunction with administrative record-keeping agencies, for the purpose of standardizing Brazil's economic data. The reference used in preparing the CNAE was the International Standard Industrial Classification of all Economic Activities (ISIC), produced by the United Nations Statistics Division.
} 
FIGURE 4

China: Herfindahl-Hirschman index of sectoral concentration of the export schedule, 1994-2008

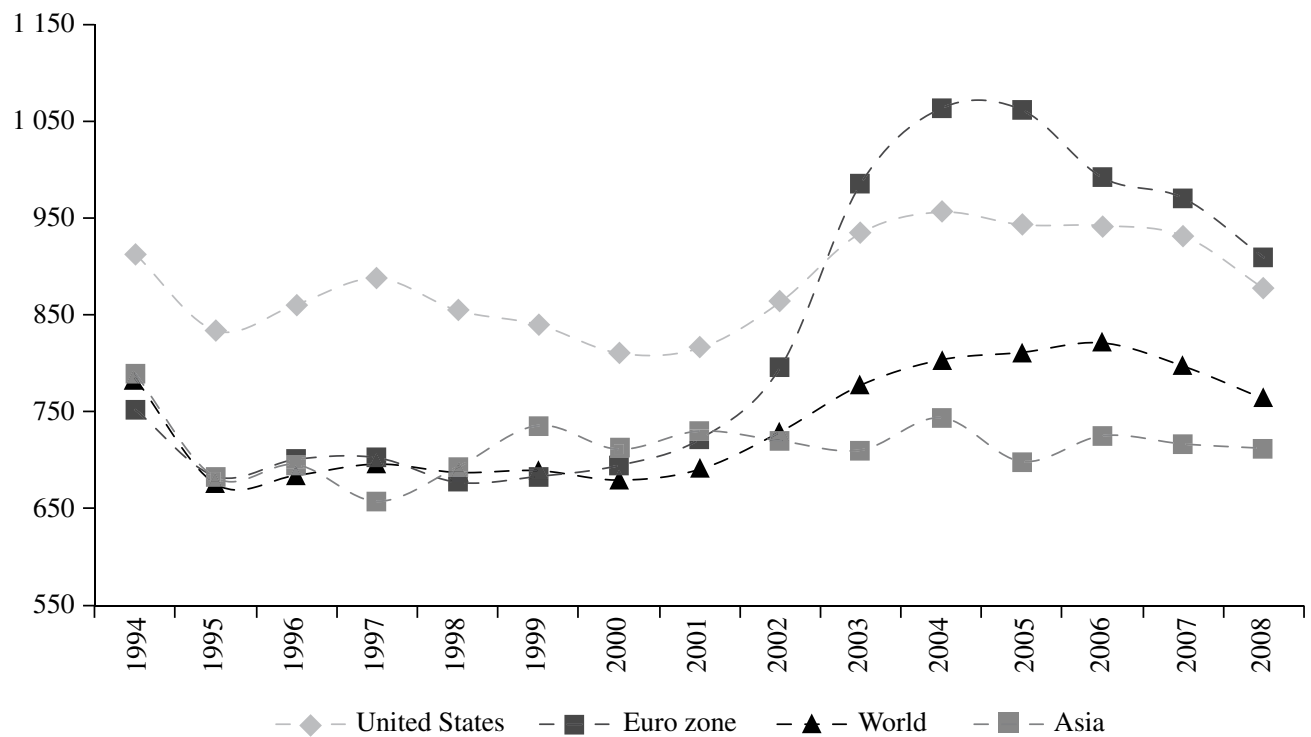

Source: United Nations Commodity Trade Database (COMTRADE).

higher value indicates an export schedule concentrated in few sectors. For further details of the HHI see Resende and Boff (2002).

The concentration of China's total external sales vary between a minimum of 675 and a maximum of 820 in the reference period, reaching a level of 763 in 2008. This represents a low-concentration model. There was a significant change in the HHI of China's exports to the United States and the euro zone between 2002 and 2005.

Given the changes in the relative importance of the different sectors in the Chinese export basket, the composition of external sales in terms of technological intensity changed between 1996 and 2008, ${ }^{17}$ as shown in table 2 .

The proportion of labour-intensive products in China's export basket declined considerably between 1996 and 2008. At the same time there has been increase

17 See the methodology described by Pavitt (1984), expanded by Holland and Xavier (2004). in manufactures produced by specialized suppliers, goods intensive in economies of scale and those intensive in research and development (R\&D). The sectors indicated as manufactures produced by specialist suppliers relate to specially commissioned capital goods. Goods intensive in economies of scale include the automotive, iron and steel industries, along with consumer electronics (mainly video, audio, and white-line appliances). China's exports are dominated by the sectors manufacturing radio and television receivers and sound and video reproduction, recording or amplification, and the manufacture of electrical appliances. Sectors involving R\&D-intensive products are fine chemicals, electronic components, telecommunications, and the aerospace industry. The sector manufacturing telephony and radio telephony apparatus and equipment, and television and radio transmitters, accounts for the largest share of China's external sales. This reflects another distinctive feature of China's performance in world trade: the capacity to add value to products in the export basket in a relatively short space of time. 


\begin{tabular}{|c|c|c|c|c|}
\hline \multirow{2}{*}{ Type } & \multicolumn{2}{|c|}{ Exports } & \multicolumn{2}{|c|}{ Imports } \\
\hline & 1996 & 2008 & 1996 & 2008 \\
\hline Commodities & 8.7 & 2.8 & 9.3 & 24.6 \\
\hline Natural-resource-intensive products & 10.4 & 8.2 & 17.9 & 14.7 \\
\hline Labour-intensive manufactures & 44.9 & 26.9 & 21.0 & 8.5 \\
\hline Economies-of-scale-intensive manufactures & 17.1 & 22.7 & 12.6 & 9.2 \\
\hline Manufactures produced by specialized suppliers & 10.5 & 22.9 & 26.0 & 17.0 \\
\hline R\&D-intensive manufactures & 7.7 & 16.3 & 13.1 & 25.7 \\
\hline Unclassified & 0.7 & 0.1 & 0.0 & 0.4 \\
\hline Total & 100 & 100 & 100 & 100 \\
\hline
\end{tabular}

Source: Global Trade Information Services (GTIS).

\section{III}

\section{The performance of Chinese and Brazilian exports in Latin America}

The previous section highlighted China's capacity to diversify its export markets and products and add greater value to its export basket. Given these characteristics, this section seeks to compare the recent path of Brazilian and Chinese exports in Latin America, to determine whether Brazilian exports risk being displaced in the region as a result of China's expansion. The initial analysis focuses on industrial exports. Figure 5 shows the estimated trend of the value of exports from sectors related industry in the Brazilian and Chinese economies to Latin American countries (in billions of dollars). ${ }^{18}$ The periods in which there were changes in those trends are also indicated. It should be remembered that indicators showing the relation between the Chinese economy and Latin American countries do not include Brazil.

When estimating the behaviour of the trend in a given time series, components associated with irregularities, seasonality, and cycles are eliminated to obtain a more robust observation of the movement of the series. Both the trend of Brazilian manufactured exports to Latin America (Brazilian trend), and the trend of Chinese exports to the same destination (Chinese trend) moved

${ }^{18}$ The statistical method used to estimate the trend is that applied in univariate structural time-series models. For further details see Harvey (1989); Commandeur and Koopman (2007). sharply upward as from 2003, when the region started to grow more vigorously (ECLAC, 2009). Nonetheless, since the second quarter of 2007 , the value of the trend of China's industrial exports to Latin America has surpassed the equivalent aggregate for the Brazilian economy. Figure 6 more clearly illustrates the dynamic of the difference between the two trends. The positive values indicate that the trend of Brazilian exports is above the trend of Chinese exports, whereas negative values indicate the reverse.

Figure 6 also shows that in 2009, when the global crisis had a major dampening effect on international trade, the difference between the Brazilian and Chinese trends was narrowing. The same conclusion arises from figure 5, which shows that the difference in the two trends widens in the initial recovery following the crisis.

Having evaluated the behaviour of industrial exports based on the respective trends, the analysis now focuses on the Chinese and Brazilian trade intensity indices with Latin America. The aggregate used to calculate this index is each country's' total exports to the Latin American region excluding Brazil. Table 3 shows China's and Brazil's TII with Latin American countries, and each country's share in Latin America's external purchases.

Although the Chinese trend outperformed Brazil's, China's trade intensity with Latin America is still less 
FIGURE 5

Estimated trend of Brazilian and Chinese industrial exports to Latin America, quarterly data from 1997 to 2009

(Billions of dollars)

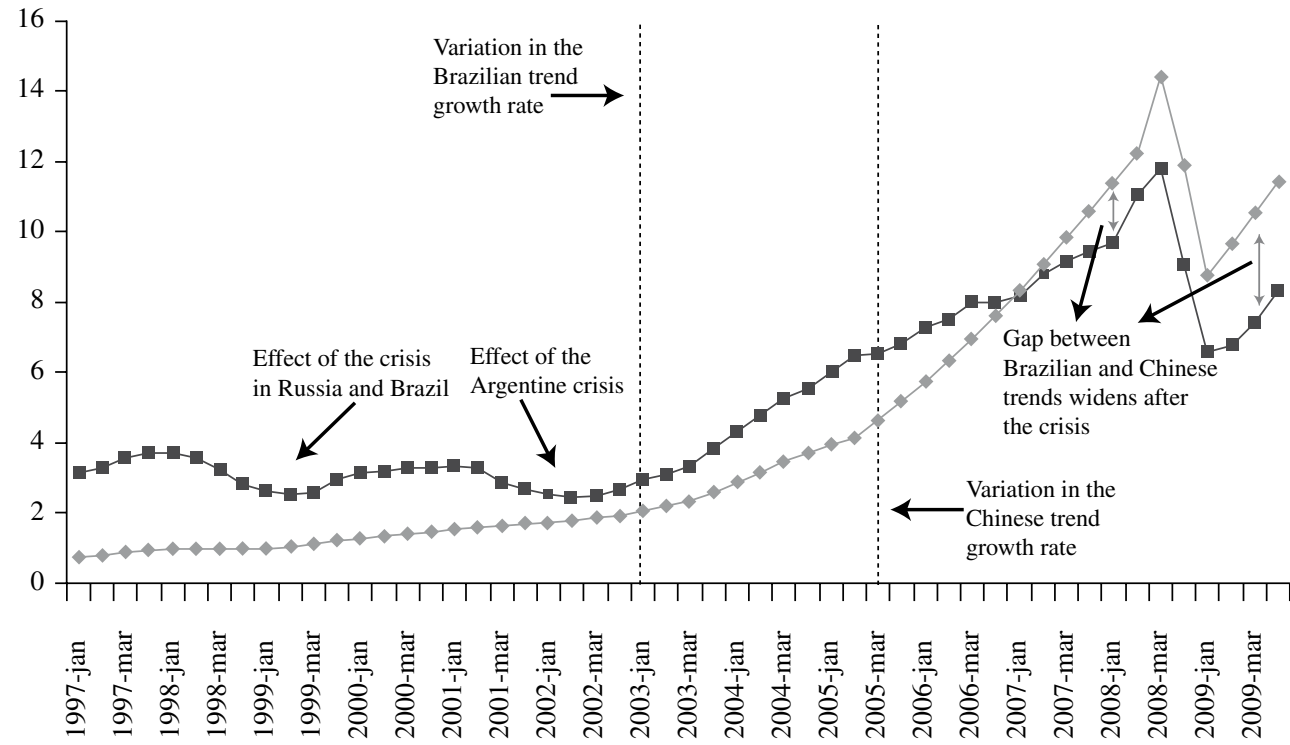

Chinese trend $\quad \longrightarrow$ Brazilian trend

Source: Global Trade Information Services (GTIS).

FIGURE 6

Difference between the trends of Brazilian and Chinese exports to Latin America, quarterly data from 1997 to 2009

(Billions of dollars)

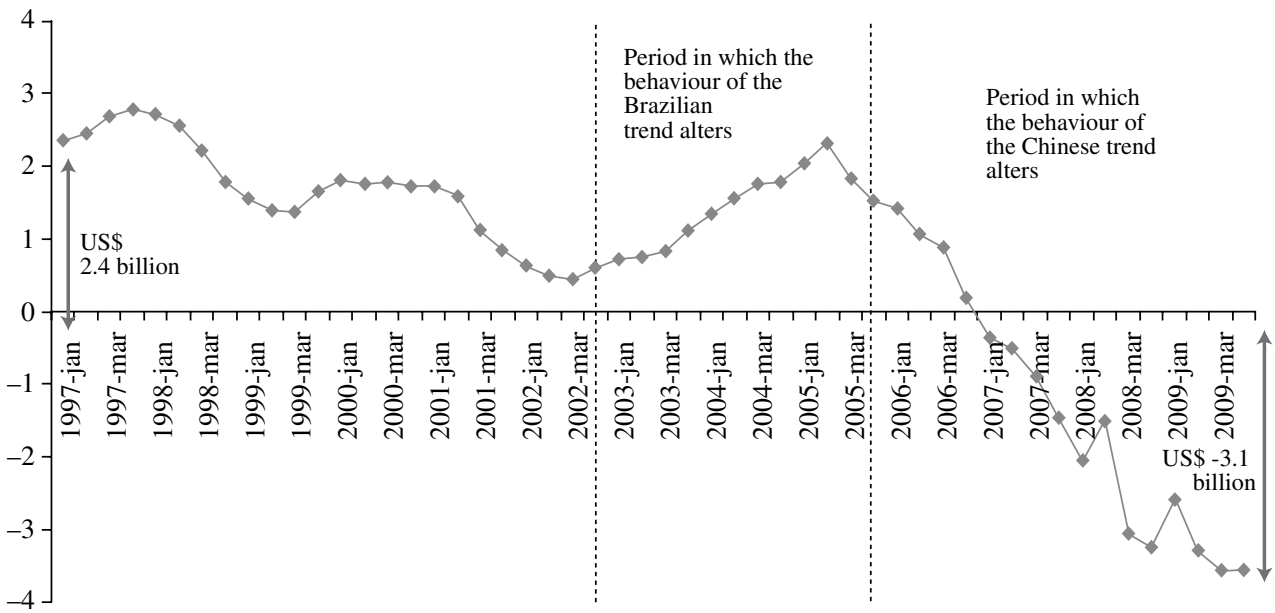

Source: Global Trade Information Services (GTIS). 
TABLE 3

China's and Brazil's tii with Latin America and the proportion of imports from those two countries in the total imports of Latin American countries, ${ }^{\mathrm{a}}$ 1994-2008

\begin{tabular}{lccccc}
\hline & \multicolumn{2}{c}{ CHINA } & & \multicolumn{2}{c}{ BRAZIL } \\
\cline { 2 - 3 } \cline { 5 - 5 } Year & IIC & Share (\%) & IIC & Share (\%) \\
\cline { 2 - 4 } 1994 & 0.25 & 0.8 & & 5.22 & 6.1 \\
1995 & 0.38 & 1.2 & & 5.58 & 5.6 \\
1996 & 0.42 & 1.3 & & 5.84 & 5.6 \\
1997 & 0.43 & 1.6 & & 5.44 & 5.7 \\
1998 & 0.49 & 1.7 & & 5.29 & 5.3 \\
1999 & 0.53 & 1.9 & & 4.78 & 4.3 \\
2000 & 0.58 & 2.4 & & 4.96 & 4.5 \\
2001 & 0.69 & 3.1 & & 4.56 & 4.5 \\
2002 & 0.74 & 3.8 & & 4.16 & 4.0 \\
2003 & 0.88 & 5.3 & 5.11 & 5.1 \\
2004 & 1.00 & 6.7 & 5.81 & 6.4 \\
2005 & 0.95 & 7.2 & 5.92 & 7.1 \\
2006 & 1.06 & 8.8 & 5.77 & 6.9 \\
2007 & 1.02 & 9.5 & 5.52 & 6.7 \\
2008 & 1.13 & 11.0 & 5.11 & 6.9 \\
\hline
\end{tabular}

Source: United Nations Commodity Trade Statistics Database (COMTRADE).

a Excluding Brazil in both cases.

TII: Trade intensity index. than Brazil's. The TII between Brazil and Latin American countries shows that trade between that region and the Brazilian economy is almost five times as large as Brazil's global trade ratio. That value does not increase steadily during the reference period, rising from $6.1 \%$ in 1994 to $6.9 \%$ in 2008. In contrast, the specific nature of China's TII with Latin America displays a substantial increase between 1994 and 2008, attaining a value of 1.13 in the latter year. In other words, the trade intensity between the Chinese economy and Latin American countries is similar to that registered between China and the world at large. Despite Brazil's greater trade intensity with Latin America compared to China's with the same region, China has the larger market share.

Table 4 shows the concentration index of China's export destinations to Latin America excluding Brazil. In 2009, 92\% of China's exports were sent to 10 Latin American markets, with $67.2 \%$ being absorbed by the four leading economies. Those figures suggest extremely high concentration, which strengthened further between 1995 and 2009. Nonetheless, between 2004 and 2009, the share of the three leading destinations for Chinese exports (CR(3)) in Latin America (excluding Brazil) decreased by $6 \%$. This suggests a slight deconcentration

TABLE 4

China: Export concentration ratio (cr) to Latin America, 1995, 1999, 2004, 2008 and 2009

(Percentages)

China: Exports to Latin America

(Excluding Brazil)

\begin{tabular}{|c|c|c|c|c|c|}
\hline & 1995 & 1999 & 2004 & 2008 & 2009 \\
\hline $\mathrm{CR}(1)$ & 26.2 & 24.9 & 36.3 & 27.6 & 30.3 \\
\hline $\mathrm{CR}(2)$ & 44.2 & 43.9 & 52.2 & 43.3 & 46.4 \\
\hline $\mathrm{CR}(3)$ & 56.2 & 58.4 & 64.6 & 55.6 & 58.6 \\
\hline CR(4) & 64.8 & 70.3 & 70.8 & 65.7 & 67.2 \\
\hline $\mathrm{CR}(5)$ & 71.2 & 75.9 & 75.4 & 72.3 & 74.1 \\
\hline CR(6) & 77.6 & 79.7 & 79.7 & 78.3 & 80.0 \\
\hline CR(7) & 82.3 & 83.2 & 82.8 & 83.8 & 85.2 \\
\hline CR(8) & 85.3 & 86.3 & 85.6 & 86.9 & 87.7 \\
\hline CR(9) & 87.6 & 88.8 & 88.1 & 89.6 & 90.1 \\
\hline CR(10) & 89.7 & 91.3 & 90.5 & 91.6 & 92.0 \\
\hline
\end{tabular}

Main destinations - rank

\begin{tabular}{|c|c|c|c|c|c|}
\hline Mexico & 4 & 2 & 1 & 1 & 1 \\
\hline Panama & 1 & 1 & 2 & 2 & 2 \\
\hline Chile & 2 & 3 & 3 & 3 & 3 \\
\hline Argentina & 3 & 4 & 4 & 4 & 4 \\
\hline Venezuela (Bolivarian Rep. of) & 8 & 6 & 6 & 5 & 5 \\
\hline Colombia & 9 & 9 & 5 & 6 & 6 \\
\hline Peru & 6 & 8 & 7 & 7 & 7 \\
\hline Ecuador & 12 & 16 & 9 & 8 & 8 \\
\hline Cuba & 5 & 5 & 10 & 9 & 9 \\
\hline Uruguay & 10 & 7 & 13 & 10 & 10 \\
\hline
\end{tabular}

Source: Global Trade Information Services (GTIS). 
trend in destinations the of China's export to Latin American countries.

To compare the concentration ratio of Brazilian and Chinese export destinations in Latin America, table 5 shows the corresponding indicator for the Brazilian economy. As in the case of China, Brazilian export destinations in Latin American countries are becoming more concentrated, particularly in Argentina. Nonetheless, the path of $\mathrm{CR}(3)$ shows a smaller deconcentration trend than in the Chinese case. The deconcentration trend of Chinese exports in the three leading Latin American destinations is greater than that achieved by Brazil.

In addition, Brazilian exports to Latin America are mostly sent to South American countries, with nine of the 10 leading destinations for Brazil's external sales to Latin American countries in that region. Mexico, which is the only exception and was the second leading destination for Brazil's exports to Latin American countries in 1999 and 2004, was ranked fourth in 2008 and third in 2009 - the year in which the repercussions of international crisis were felt. The dynamic of China's exports to Latin American countries is more decentralized, with one country from each region among its three leading destinations: North America, Central America and South America.
Brazil's top two export markets in Latin America are also among China's three main destinations in South America (excluding Brazil). As can be seen in table 3, variations in the structure of China's exports in the South American region may have been one of the factors that prevented Brazil from increasing its share in the total external purchases of Latin American countries. Here it is worth noting the trend of the ranking of China and Brazil in the total imports of Argentina and the Bolivarian Republic of Venezuela. In the case of Argentina, imports from Brazil grew by an average of $9.2 \%$ per year between 2004 and 2009. In contrast, the same indicator for China reports $40.6 \%$ annual growth over the same period The share of Brazilian products in Argentina's total imports fell from 34.6\% to $30.9 \%$, whereas the proportion of imports from China increased from $4.1 \%$ to $13.0 \%$ between 2004 and 2009 . Table 6 gives details of subsectors ${ }^{19}$ in which the share of imports from Brazil declined substantially, as the

19 The subsectors category used in this section corresponds to the three-digit breakdown of the National Classification of Economic Activities (CNAE), obtained from the International Standard Industrial Classification (ISIC) produced by the United Nations.

TABLE 5

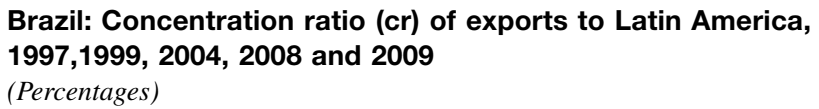

Brazil: Exports to Latin America

\begin{tabular}{|c|c|c|c|c|c|}
\hline & 1997 & 1999 & 2004 & 2008 & 2009 \\
\hline $\mathrm{CR}(1)$ & 47.6 & 48.6 & 34.9 & 38.9 & 41.0 \\
\hline $\mathrm{CR}(2)$ & 57.5 & 58.3 & 53.7 & 50.3 & 52.5 \\
\hline CR(4) & 72.1 & 73.1 & 72.7 & 70.4 & 69.7 \\
\hline $\mathrm{CR}(5)$ & 77.9 & 79.2 & 77.6 & 75.9 & 75.4 \\
\hline CR(6) & 83.3 & 84.1 & 81.8 & 80.9 & 80.8 \\
\hline $\mathrm{CR}(7)$ & 88.4 & 88.1 & 84.9 & 86.1 & 85.6 \\
\hline $\mathrm{CR}(8)$ & 91.5 & 91.7 & 87.9 & 89.7 & 89.9 \\
\hline CR(9) & 94.5 & 94.1 & 90.4 & 92.2 & 92.9 \\
\hline CR(10) & 96.5 & 95.3 & 92.8 & 94.1 & 94.9 \\
\hline
\end{tabular}

Main destinations - rank

\begin{tabular}{|c|c|c|c|c|c|}
\hline Argentina & 1 & 1 & 1 & 1 & 1 \\
\hline Venezuela (Bolivarian Rep. of) & 6 & 6 & 4 & 2 & 2 \\
\hline Mexico & 5 & 2 & 2 & 4 & 3 \\
\hline Chile & 3 & 3 & 3 & 3 & 4 \\
\hline Colombia & 8 & 8 & 5 & 7 & 5 \\
\hline Paraguay & 2 & 4 & 6 & 5 & 6 \\
\hline Peru & 9 & 9 & 8 & 6 & 7 \\
\hline Uruguay & 4 & 5 & 7 & 8 & 8 \\
\hline Bolivia (Plurinational State of) & 7 & 7 & 9 & 9 & 9 \\
\hline Ecuador & 11 & 11 & 10 & 10 & 10 \\
\hline
\end{tabular}

Source: Global Trade Information Services (GTIS). 

and China in total imports of selected subsectors, 2004 and 2009

(Percentages)

\begin{tabular}{|c|c|c|c|c|c|c|}
\hline \multirow{2}{*}{ Subsectors } & \multicolumn{2}{|c|}{ Brazil } & \multicolumn{2}{|c|}{ China } & \multicolumn{2}{|c|}{ Variation in share } \\
\hline & 2004 & 2009 & 2004 & 2009 & Brazil & China \\
\hline Fabrics - including yarn and fabric & 47.7 & 32.6 & 3.5 & 33.8 & -15.1 & 30.3 \\
\hline Textile articles & 87.0 & 63.6 & 1.3 & 15.7 & -23.4 & 14.4 \\
\hline Woollen fabrics and articles & 38.7 & 9.9 & 1.0 & 61.7 & -28.8 & 60.8 \\
\hline Clothing manufacture & 37.0 & 8.6 & 4.8 & 43.7 & -28.4 & 38.9 \\
\hline Footwear & 74.4 & 55.4 & 10.2 & 27.7 & -19.1 & 17.5 \\
\hline Pharmaceuticals & 14.2 & 6.8 & 10.6 & 20.4 & -7.4 & 9.8 \\
\hline Ceramics & 42.0 & 30.3 & 8.5 & 26.0 & -11.7 & 17.5 \\
\hline Electrical appliances & 49.7 & 35.1 & 15.0 & 34.0 & -14.5 & 19.0 \\
\hline Electrical generators, transformers and motors & 21.0 & 12.2 & 5.8 & 12.8 & -8.8 & 7.0 \\
\hline Insulated electrical wires, cables and conductors & 53.8 & 29.1 & 3.6 & 22.4 & -24.7 & 18.8 \\
\hline Lamps and lighting equipment & 26.5 & 12.2 & 30.9 & 60.4 & -14.3 & 29.5 \\
\hline Basic electronic material & 13.0 & 3.7 & 8.4 & 27.1 & -9.4 & 18.7 \\
\hline Radio, television, sound and video & 14.6 & 5.8 & 13.9 & 53.0 & -8.7 & 39.1 \\
\hline Optical, photographic and cinematographic apparatus & 15.3 & 8.2 & 12.7 & 44.2 & -7.1 & 31.5 \\
\hline Vehicle cabins, chassis and trailers & 78.4 & 51.8 & 3.7 & 20.0 & -26.6 & 16.4 \\
\hline Furniture items & 50.9 & 39.6 & 8.8 & 20.2 & -11.3 & 11.3 \\
\hline
\end{tabular}

Source: Global Trade Information Services (GTIS).

share of imports from the Chinese economy grew in the total imports of the subsector by the Argentine market.

Increases in the share of imports from China compared to those from Brazil have occurred particularly in labour-intensive subsectors (manufacture of textile products, footwear and furniture items) and electroelectronics generally. From the Brazilian standpoint, the situation of exports to the Bolivarian Republic of Venezuela, its second ranked destination in Latin America, is more worrying than that of Argentina. Between 2004 and 2009, imports from Brazil grew at an average annual rate of $16.5 \%$. In contrast, Chinese exports to the Bolivarian Republic of Venezuela grew by an average of over $54 \%$ per year. Thus, while the share of imports from Brazil decreased from $8.3 \%$ of Venezuela's total imports in 2003 to $7.4 \%$ in 2009 , the share of imports from China grew from $2.9 \%$ to $10.6 \%$ in the same period. In 2009, the year in which the international economic crisis worsened, the share of imports from China in the Venezuelan market grew by $0.8 \%$, whereas the share of imports from Brazil decreased by around $0.9 \%$. Table 7 shows the main subsectors in which imports of Brazilian origin lost share and those from China gained, compared to the total external purchases by the subsector in question in the Bolivarian Republic of Venezuela.

These figures reveal two specific features of China's exports to Brazil's two leading markets in Latin America. The first relates to the capacity to gain positions with respect to Brazilian exports in an international crisis setting. This dynamic had been mentioned above when describing the trend of China's exports of industrial products in all Latin American countries, as shown in figure 5. The second specific feature concerns its expansion capacity in most industrial subsectors. This is even clearer when comparing the results shown in tables 6 and 7, which show a considerable number of non-coinciding subsectors in the economies of Argentina and the Bolivarian Republic of Venezuela. That situation had been noted in the previous section, dealing with the performance of China's exports worldwide. To demonstrate the sectoral deconcentration capacity of China's exports in Latin American countries, figure 7 shows the Herfindahl-Hirschman index of Chinese and Brazilian external sales to Latin American countries.

Brazilian exports to Latin American countries reveal a slight sectoral deconcentration trend. In 2009, $53.8 \%$ of those exports were concentrated in four sectors, namely manufacture and assembly of motor vehicles, trailers and chassis $(22.6 \%)$; manufacture of chemical products $(11.1 \%)$; machinery and equipment $(10.7 \%)$; and basic metallurgy (9.4\%). In terms of the dynamic of Chinese exports, there is a sector deconcentration movement associated with a change in composition, with higher value-added sectors gaining importance.

The accumulation of value in China's exports to Latin American countries is clear, since in the first year of the series, the main sectors were clothing manufacture and accessories $(21.2 \%)$; manufacture 
TABLE 7

Bolivarian Republic of Venezuela: Share and a variation in the share of imports from Brazil and China in total imports by selected subsectors, 2004 and 2009

(Percentages)

\begin{tabular}{|c|c|c|c|c|c|c|}
\hline \multirow{2}{*}{ Subsectors } & \multicolumn{2}{|c|}{ Brazil } & \multicolumn{2}{|c|}{ China } & \multicolumn{2}{|c|}{ Variation of Share } \\
\hline & 2004 & 2009 & 2004 & 2009 & Brazil & China \\
\hline Fabrics, including yarn and fabric & 9.1 & 4.2 & 22.1 & 29.3 & -4.9 & 7.2 \\
\hline Footwear & 11.1 & 8.6 & 4.9 & 25.7 & -2.5 & 20.8 \\
\hline Wood products, cork and braided material, except furniture & 37.8 & 27.3 & 7.0 & 18.4 & -10.5 & 11.4 \\
\hline $\begin{array}{l}\text { Continuous fibres, yarns, cables and filaments, artificial and } \\
\text { synthetic }\end{array}$ & 5.8 & 1.4 & 1.5 & 24.8 & -4.4 & 23.3 \\
\hline Glass and products of glass & 14.3 & 5.6 & 3.1 & 22.9 & -8.7 & 19.8 \\
\hline Tanks, boilers and metallic deposits & 9.2 & 1.8 & 4.4 & 13.0 & -7.4 & 8.6 \\
\hline Machine-tools & 12.8 & 7.1 & 4.4 & 16.4 & -5.7 & 12.0 \\
\hline $\begin{array}{l}\text { Machinery and equipment used for mineral extraction and } \\
\text { construction }\end{array}$ & 22.2 & 14.3 & 3.1 & 11.8 & -7.9 & 8.7 \\
\hline Other machinery and equipment of specific use & 15.9 & 9.5 & 2.6 & 9.9 & -6.4 & 7.3 \\
\hline Electrical appliances & 6.6 & 3.4 & 9.2 & 19.5 & -3.2 & 10.3 \\
\hline Lamps and lighting equipment & 8.7 & 1.5 & 21.9 & 44.8 & -7.2 & 22.9 \\
\hline Other transport equipment & 2.6 & 0.3 & 23.7 & 50.0 & -2.3 & 26.3 \\
\hline Furniture items & 8.3 & 7.2 & 8.4 & 26.2 & -1.1 & 17.8 \\
\hline
\end{tabular}

Source: Global Trade Information Services (GTIS).

FIGURE 7

Herfindahl-Hirschman index of sector concentration of Chinese and Brazilian exports to Latin America, 1995-2008

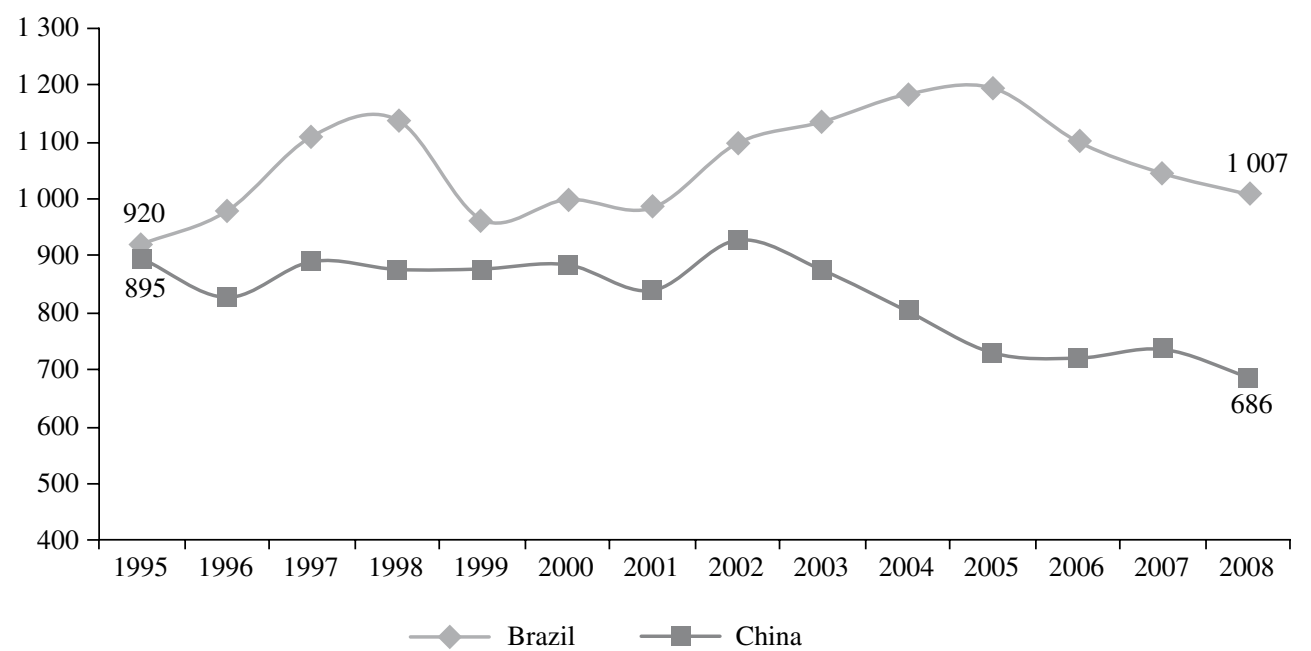

Source: United Nations Commodity Trade Database (COMTRADE).

of textile products $(15.3 \%)$; preparation of leather and manufacture of leather articles, travel articles and footwear (7.9\%); and machinery and equipment (7.1\%). By 2008, in contrast, the four leading export sectors to Latin America were the manufacture of electronic material and communications apparatus and equipment (12.1\%); machinery and equipment $(10.8 \%)$; manufacture of chemical products $(8.7 \%)$; and manufacture of textile products $(8.2 \%)$. In other words, as the share of labour-intensive activities decreases, the importance of manufactures produced by specialized suppliers and R\&D-intensive products increases. 
To analyse these findings in greater depth, the trade complementarity index (TCI) was calculated for Chinese and Brazilian trade with Latin American countries, again remembering that indicators relating to that region do not include Brazil. The TCI between the two regions is obtained by comparing the export basket of country $i$ to the world at large, with the total import basket of country $j$. For the purposes of this article, it is possible to verify the extent to which products exported by Brazil and China worldwide coincide with the products imported by Latin American countries. The TCI is calculated using the following formula, where the sector characterization used to calculate the share in total imports and exports is the CNAE version 1.0, at the three-digit level:

$$
T C I_{i, j}=100-\sum_{k=1}^{n}\left[\frac{\left|m_{k, j}-x_{k, i}\right|}{2}\right]
$$

Where: $m_{k, j}=$ Represents imports of sector $k$ in the total imports of country $j ; x_{k, i}=$ represents exports of sector $k$ in the total exports of country $i$.

A TCI of zero means that there is no complementarity between the imports and exports of the regions analysed, whereas if the indicator has a value of a 100 , it means that the schedules are perfectly complementary; i.e. the country in question exports precisely what the other country wants to import. ${ }^{20}$ Figure 8 shows the dynamic of the TCI for China and Brazil with respect to Latin America.

In the reference period, China's TCI with Latin American countries increased, while Brazil's TCI with those countries declined. Although a TCI value above 50 points indicates a high level of complementarity, in 2008 China's complementarity with Latin America was greater than Brazil's, because the indicators for the two countries in 1994 were 47.6 and 56.9 respectively. The subsectors recording an increase in the TCI of China's exports and Latin America's imports include the manufacture of optical, photographic and cinematographic apparatus, instruments and materials, for which the index rose from 46.6 in 1994 to 87.5 in 2008. This increase in complementarity stems from annual average growth of over 35\% in China's exports from that subsector to Latin American countries in the years studied. The value exported by the Chinese economy to the region thus reached a level of US $\$ 1.5$ billion in the last year considered.

The TCI of the ceramics manufacturing subsector rose by 36.1 points between 1994 and 2008, reaching a level of 59.0, representing an increase in the share

\footnotetext{
${ }^{20}$ See Hoekman, Mattoo and English (2002) for further details.
}

FIGURE 8

\section{Trade complementarity index between Brazil and Latin America and between China and Latin America, 1994-2008}

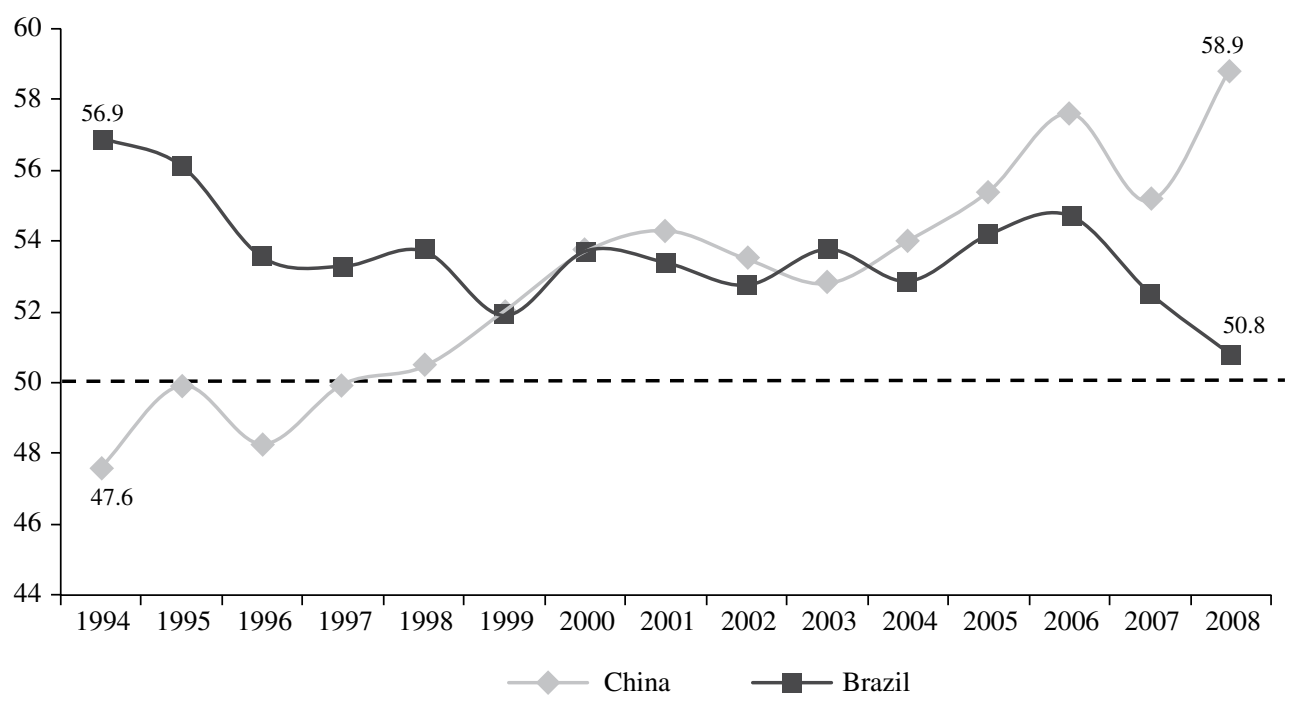

Source: United Nations Commodity Trade Database (COMTRADE). 
of that subsector's imports from China from $3.8 \%$ to $28.2 \%$ with respect to total Latin American imports in that subsector. Moreover, there was an increase of over 32 points in China's TCI with Latin American countries, in relation to the electric energy distribution and control equipment manufacture subsector, which in 2008 attained a level of 76.6 .

Thus far, the analysis has focused on the general features of the Brazilian and Chinese export baskets to Latin America, highlighting the sectors and subsectors considered most important. The next indicator to be reviewed involves a subsector approach, defining annual gains and losses of a set of subsectors present in Brazilian and Chinese exports to Latin American countries.

This method of analysis is based on the hypothesis that a country's share in world markets should remain constant through time. The difference between export growth defined by that constant share standard and the observed export performance is attributed to the competitiveness effect; and real export growth is divided into competitiveness, export basket composition, and market distribution effects (Leamer and Stern, 1970, p. 171). For that purpose, the competitiveness effect measure (CE) is used, which relates changes in the market share and value exported from Brazil and China by subsectors, as follows:

$$
C E_{j}^{k}=\left(\frac{m_{i, j, t}^{k}}{M_{i, w, t}^{k}}-\frac{m_{i, j,(t-1)}^{k}}{M_{i, w,(t-1)}^{k}}\right) \times M_{i, w, t}^{k}
$$

Where: $\frac{m_{i, j, t}^{k}}{M_{i, w, t}^{k}}=$ share of country $j$ in the imports of country $i$ of sector $k$ in the final period $t ; \frac{m_{i, j,(t-1)}^{k}}{M_{i, w,(t-1)}^{k}}=$ share of country $j$ in the imports of country $i$ of sector $k$ in the initial period ( $t-1)$; and $M_{i, w, t}^{k}=$ total value of imports of country $i$ of sector $k$ in the final period $t$.

The competitiveness effect is calculated as the difference between the value actually exported by each subsector from the Chinese and Brazilian economies in the last year analysed, and the value that should have been exported for each country to maintain the same market shares in the initial year of the analysis. Thus, if the competitiveness effect is equal to zero, it means that there was no competitiveness gain. The competitiveness effect will be used to measure the net gain or loss of competitiveness of the exports of each Brazilian and Chinese subsector to Latin America. ${ }^{21}$ It would also be possible to review the product and market effects on changes in sector shares, but the competitiveness effect is sufficient for the specific purpose of comparing the performance of Chinese and Brazilian exports.

Table 8 shows the competitiveness effect for selected subsectors. Those subsectors were defined on the basis of choosing those showing a net average competitiveness

${ }^{21}$ See Leamer and Stern (1970); Batista (2002).

TABLE 8

Gain and loss of competitiveness of selected sectors of Brazilian and Chinese exports to Latin America, 1994-2008 and 2003-2008

(Thousands of dollars per year)

\begin{tabular}{|c|c|c|c|c|c|}
\hline \multirow{2}{*}{ Country } & \multirow{2}{*}{ Subsector } & \multicolumn{2}{|c|}{ China } & \multicolumn{2}{|c|}{ Brazil } \\
\hline & & 1994-2008 & $2003-2008$ & 1994-2008 & 2003-2008 \\
\hline $\mathrm{BR}$ & Extraction of oil and natural gas & 8 & -147 & 121942 & 207429 \\
\hline BR & Livestock & -241 & -846 & 30363 & 77845 \\
\hline BR & Slaughtering and preparation of meat and fish products & 9404 & 14644 & 25024 & -8949 \\
\hline BR & Tractors and machinery and equipment for agriculture & 4103 & 9666 & 22403 & 10579 \\
\hline BR & Soaps, detergents, cleaning products and perfume articles & 5093 & 7265 & 21977 & 33016 \\
\hline BR & Dairy products & 1384 & 3836 & 17270 & 45550 \\
\hline $\mathrm{BR}$ & Construction, assembly and repair of aircraft & 177 & 67 & 14474 & 21165 \\
\hline BR & Seasonal crops & 2093 & -23802 & 13302 & 5599 \\
\hline $\mathrm{BR}$ & Production of alcohol & 0.00 & -0.04 & 12835 & 28334 \\
\hline BR./CH & Automobiles, trucks and utility vehicles & 20983 & 55648 & 182257 & 62840 \\
\hline BR./CH & Pesticides & 23701 & 38549 & 13261 & 37587 \\
\hline BR./CH & Non-ferrous metal metallurgy & 31254 & 63946 & 28019 & 62699 \\
\hline BR./CH & Machinery and equipment for use in mineral extraction and construction & 33991 & 85410 & 19732 & -15981 \\
\hline
\end{tabular}


Table 8 (concluded)

\begin{tabular}{|c|c|c|c|c|c|}
\hline \multirow{2}{*}{ Country } & \multirow{2}{*}{ Subsector } & \multicolumn{2}{|c|}{ China } & \multicolumn{2}{|c|}{ Brazil } \\
\hline & & 1994-2008 & 2003-2008 & 1994-2008 & 2003-2008 \\
\hline BR./CH & Inorganic chemical products & 62379 & 109232 & 13670 & 23164 \\
\hline BR./CH & Footwear & 64707 & 43321 & 12495 & -20315 \\
\hline $\mathrm{BR} . / \mathrm{CH}$ & Pharmaceuticals & 127422 & 258534 & 14349 & -22359 \\
\hline $\mathrm{BR} . / \mathrm{CH}$ & Telephony, radio telephony and television and radio transmission & 508102 & 1135711 & 137401 & 211079 \\
\hline BR./CH & Construction and repair of ships & 12933 & 35239 & 14474 & 21165 \\
\hline $\mathrm{CH}$ & Professional safety clothing accessories & 11772 & 27313 & 31 & 204 \\
\hline $\mathrm{CH}$ & Fibres, wires, cables and continuous filaments, artificial and synthetic & 10060 & 25231 & -498 & -6127 \\
\hline $\mathrm{CH}$ & Office machinery & 15045 & 12003 & 3421 & 11244 \\
\hline $\mathrm{CH}$ & Products of wood, cork and braided material - except furniture & 16409 & 34770 & -4284 & -291 \\
\hline $\mathrm{CH}$ & Electrical material for vehicles - except batteries & 18212 & 43055 & 2269 & 34570 \\
\hline $\mathrm{CH}$ & Miscellaneous chemical products and preparations & 20064 & 25284 & -10103 & -8317 \\
\hline $\mathrm{CH}$ & Resins and elastomers & 20872 & 45757 & -28650 & 3946 \\
\hline $\mathrm{CH}$ & Measurement, testing and control apparatus and instruments $\mathrm{a}^{\mathrm{a}}$ & 22238 & 45449 & -1689 & 5503 \\
\hline $\mathrm{CH}$ & Glass and glass products & 23803 & 41828 & 2364 & 14271 \\
\hline $\mathrm{CH}$ & Trucks and buses & 24163 & 65109 & -18779 & 113127 \\
\hline $\mathrm{CH}$ & Other electrical equipment and apparatus & 27232 & 44297 & -2540 & 4522 \\
\hline $\mathrm{CH}$ & Instruments for medical-hospital use $\mathrm{e}^{\mathrm{b}}$ & 18814 & 40748 & -378 & 8698 \\
\hline $\mathrm{CH}$ & Equipment for distribution and control of electric energy & 27319 & 51905 & -4131 & 14290 \\
\hline $\mathrm{CH}$ & Electric batteries and accumulators & 30651 & 51942 & 3124 & 16465 \\
\hline $\mathrm{CH}$ & Textile articles made from fabrics - except clothing & 30934 & 70335 & 7124 & 28406 \\
\hline $\mathrm{CH}$ & Machinery-tools & 32850 & 66920 & 3614 & 2560 \\
\hline $\mathrm{CH}$ & Tubes - except iron and steel & 35126 & 85877 & 9778 & 34031 \\
\hline $\mathrm{CH}$ & Woollen fabrics and articles & 38251 & 61283 & -9609 & 2648 \\
\hline $\mathrm{CH}$ & Ceramic products & 38334 & 82600 & 666 & 1285 \\
\hline $\mathrm{CH}$ & Travel articles and miscellaneous leather articles & 39109 & 46725 & 1830 & 6885 \\
\hline $\mathrm{CH}$ & Metalwork articles and instruments, locks and manual tools & 44051 & 91996 & -7021 & 21968 \\
\hline $\mathrm{CH}$ & Furniture items & 48196 & 93608 & 7410 & 28976 \\
\hline $\mathrm{CH}$ & Other machinery and equipment of specific use & 48760 & 111798 & 5892 & 18391 \\
\hline $\mathrm{CH}$ & Organic chemical products & 50500 & 59900 & -22396 & 23443 \\
\hline $\mathrm{CH}$ & Spare parts and accessories for motor vehicles & 55711 & 136154 & -124549 & 270715 \\
\hline $\mathrm{CH}$ & Fabrics - including yarn and fabric & 58492 & 110611 & 4454 & 6899 \\
\hline $\mathrm{CH}$ & Lamps and lighting equipment & 58511 & 71484 & -2461 & -1481 \\
\hline $\mathrm{CH}$ & Motors, pumps, compressors and transmission equipment & 78693 & 142070 & -3026 & 55897 \\
\hline $\mathrm{CH}$ & Miscellaneous metal products & 82944 & 172942 & -367 & 33517 \\
\hline $\mathrm{CH}$ & Other transport equipment & 84334 & 108130 & 7655 & 4778 \\
\hline $\mathrm{CH}$ & Electrical appliances & 85983 & 130241 & -2803 & -22110 \\
\hline $\mathrm{CH}$ & Plastic products & 89971 & 172458 & 2847 & 47048 \\
\hline $\mathrm{CH}$ & Optical, photographic and cinematographic apparatus & 91916 & 114099 & -6059 & -8273 \\
\hline $\mathrm{CH}$ & Garment manufacture & 96984 & 154763 & -2625 & -1039 \\
\hline $\mathrm{CH}$ & Machinery and equipment of general use & 116118 & 252846 & -12695 & 9604 \\
\hline $\mathrm{CH}$ & Electrical generators, transformers and motors & 116438 & 206431 & -5565 & 45015 \\
\hline $\mathrm{CH}$ & Iron and steel & 117106 & 315229 & -76199 & 411 \\
\hline $\mathrm{CH}$ & Basic electronic material & 182325 & 270257 & -10083 & -8248 \\
\hline $\mathrm{CH}$ & Radio, television, sound and video & 424964 & 458761 & 8269 & -40883 \\
\hline $\mathrm{CH}$ & Electronic system equipment for data processing & 580361 & 640900 & 433 & -5275 \\
\hline & Total - all subsectors & 4445013 & 7428127 & 110019 & 1768881 \\
\hline
\end{tabular}

Source: United Nations Commodity Trade Database (COMTRADE).

a Except equipment used in the control of industrial processes.

b This subsector includes apparatus and instruments for medical-hospital, dental and laboratory uses, and orthopaedic apparatus. BR: Brazil. $\mathrm{CH}$ : China. 
gain of more than US $\$ 10$ million per year, considering the change between the years 1994 and 2008, referred to as long period. The "country" column indicates the country to which the subsector belongs. A second period of analysis from 2003 to 2008 is referred to as the "short period", because, as shown above, in 2003 there was a change in the trend of Brazilian exports to America.

An analysis of the long period shows that nine subsectors produced exclusive competitiveness gains for Brazilian exports, 11 subsectors recorded competitiveness gains in amounts above US\$10 million per year in both countries, and 40 subsectors were defined by competitiveness gains for Chinese exports. This result shows the competitive superiority of China's exports to Latin American countries, compared to Brazil's exports to the same destinations. China's net total competitiveness gain in the long period, including subsectors that are not identified in table 8 , amounts to US $\$ 4,445$ million per year, translating into a net gain of US\$62.2 billion over the entire period analysed. In contrast, the net total competitiveness gain of Brazilian exports to Latin America amounted to US\$110 million per year, for a cumulative value of US $\$ 1.5$ billion. The superiority of China's exports to the region is clear when comparing the results, because their competitiveness gain is 40 times higher than that of Brazil's exports to the same group of countries. The reader is reminded that this superior performance model of China's exports had been defined in the indicator series shown above.

On the other hand, there has been a considerable improvement in the net total competitiveness gain of Brazilian exports in the short period, in other words since 2003. Between 2003 and 2008, this value amounted to US $\$ 1,769$ million per year, for a cumulative value of US\$8.9 billion. Despite this recovery in the competitiveness of Brazil's exports to Latin American countries, the total net competitiveness gain for China was even higher, reaching a level of US\$7,428 million

\section{IV}

\section{Final comments}

This article has reviewed Chinese and Brazilian export performance of in Latin America. It started by evaluating the importance of the external sector in China's growth dynamic, and showed that GFCF has contributed more than net exports to GDP growth. As per year, or a cumulative US $\$ 37.1$ billion over the short period. This shows that the total net competitiveness gain for China's exports to Latin America in the long period was well distributed, and that $67 \%$ of those gains were obtained in the short period. The characterization of Brazilian exports shows that total net competitiveness gains were heavily concentrated in the short period.

The nine subsectors selected for exclusive competitiveness gains by Brazilian exports display a concentration in natural-resource-intensive activities. The subsector recording the largest competitiveness gain in the long period was oil and gas extraction, and the gain was intensified in the short period. In this group of nine subsectors, the only ones not relating to natural resource intensive products are the following: Tractors and machinery and equipment agriculture; Construction, assembly and repair of aircraft; and soaps, detergents, cleaning products and perfume articles. It is worth noting that the first subsector mentioned is formed by multinationals, whereas the second is based on performance of a single enterprise.

An analysis of the nine selected subsectors shows that the competitiveness of Brazilian exports compared to Chinese exports to Latin America is increasing in natural-resource-intensive subsectors, the manufacture of tractors and agricultural implements, and in the aviation sector. Since 2003 there has been a recovery in the competitiveness of the automotive chain, including parts and accessories manufacture. In the other subsectors -mainly electro-electronics, machinery and labour-intensive equipment- China is clearly more competitive. In other words, Brazilian exports have become more competitive than those of China in just 10 of the 60 subsectors listed in table 8 . The capacity of the Chinese economy to diversify and add value to its export basket for Latin America, shown in this subsectorcompetitiveness model, had been noted above when reviewing the external sales of that country worldwide. argued in the section II, however, this does not mean that exports are unimportant.

The analysis showed that the trend of China's exports of industrialized products to Latin America outpaced the Brazilian equivalent. This divergence becomes more 
accentuated as from 2005, despite an increase in the growth rate of Brazilian exports from industrial sectors to Latin American countries in 2003. Nonetheless, the trend of China's industrial exports to Latin America, in value terms, has outpaced the equivalent indicator for Brazilian exports since the second quarter of 2007. Moreover, related to the virtuous dynamic of the trend of China's exports to Latin American countries, the share of imports from China in Latin America's total imports has grown, and trade intensity has also increased between the two regions. In contrast, the share of imports from Brazil in the total imports of Latin American countries stagnated between 1994 and 2008, as did Brazil's trade intensity index (TII) with Latin America.

In terms of the quality of China's exports to Latin America, a sectoral deconcentration process has been unfolding, along with an increase in the relative share of higher value-added sectors during the years analysed in this article. This deconcentration of external sales from the Chinese economy to Latin America was not merely sectoral, because from 2004 on a deconcentration trend has been visible in China's exports to its three main Latin American partners. In counterpart, the sectoral concentration of Brazil's exports to Latin America has increased slightly, with a heavy concentration of those exports in South American countries, particularly in Argentina.

The superior performance of China's exports to Latin America compared with those of Brazil is also reflected in those two countries' TCIs with the Latin American region -increasing in China's trade with Latin America but decreasing in the case of Brazil. At the subsector level, Brazilian exports have become more competitive basically in natural-resource intensive sectors; tractors and agricultural equipment; and aviation, while the automotive chain staged a recovery between 2003 and 2008. In all other sectors, Chinese exports has shown a clear advantage. This resulted in a net competitiveness gain for Chinese exports to Latin America that is 40 times greater than the same indicator for the Brazilian economy in the period 1994-2008, considering all export subsectors.

(Original: Portuguese)
ADC (Andean Development Corporation) (2006), América Latina en el comercio global: ganando mercados, Caracas.

Batista, J.C. (2002), "Desvalorização cambial e as exportações brasileiras para os Estados Unidos", Revista brasileira de comércio exterior, vol. 15, No. 70, Rio de Janeiro, Centre for Foreign Trade Studies Foundation (FUNCEX), January-March.

Bijian, Z. (2006), "The internal and external environments of China's development over the next five years", East Asian Visions, I. Gill, Y. Huang and H. Kharas, Washington, D.C., World Bank.

Castro, A.B. (2008), "From semi-stagnation to growth in a sinocentric market", Brazilian Journal of Political Economy, vol. 28, No. 1, São Paulo, Centro de Economia Política, January-March.

Commandeur, J.J.F. and S.J. Koopman (2007), Practical Econometrics. An Introduction to State Space Time Series Analysis, Oxford, Oxford University Press.

Devlin, R., A. Estevadeordal and A. Rodríguez-Clare (eds.) (2006), The Emergence of China: Opportunities and Challenges for Latin America and the Caribbean, Washington, D.C., InterAmerican Development Bank.

ECLAC (Economic Commission for Latin America and the Caribbean) (2009), Latin America and the Caribbean in the World Economy 2008-2009. Crisis and Opportunities for Regional Cooperation (LC/G.2413-P), Santiago, Chile. United Nations publication, Sales No. E.09.II.G.62.

Felipe, J. and others (2010), "Why has China succeeded - And why it will continue to do so", Economics Working Paper Archive, No. 611, Levy Economics Institute, August [online] http:// www.levyinstitute.org/pubs/wp_611.pdf.

Goldman Sachs (2007), brics and Beyond, Global Economics Department, The Goldman Sachs Group [online] http://www2. goldmansachs.com/ideas/brics/BRICs-and-Beyond.html.

Gross, B. (2009), "On the "course" to a new normal", Investment Outlook, September, PIMCo [online] www.pimco.com/LeftNav/
Featured+Market+Commentary/IO/2009/Gross+Sept+On+the+ Course+to+a+New+Normal.htm.

Guo, K. and P. N'Diaye (2000), "Is China's export-oriented growth sustainable?", imf Working Paper, No. 09/172, Washington, D.C., International Monetary Fund, August [online] http:// www.imf.org/external/pubs/ft/wp/2009/wp09172.pdf.

Harvey, A.C. (1989), Forecasting, Structural Time Series Models and the Kalman Filter, Cambridge, Cambridge University Press.

Harvey, A.C. and N. Shepard (1993), "Structural time series models", Handbook of Statistics, vol. 11, G.S. Maddala, C.R. Rao and H.D. Vinod (eds.), Elsevier Science Publishers B.V.

Hoekman, B.M., A. Mattoo and P. English (2002), Development, Trade, and the wto: A Handbook, Washington, D.C., World Bank.

Holland, M. and C.L. Xavier (2004), "Dinâmica e competitividade setorial das exportações brasileiras: uma análise de painel para o período recente", Anais do XXXII Encontro Nacional de Economia, No. 058, Ingá Niterói, National Association of Centers for Post-graduation in Economics (ANPEC).

Kang, D.C. (2007), China Rising: Peace, Power and Order in East Asia, New York, Columbia University Press.

Kurlantzick, J. (2007), Charm Offensive: How China's Soft Power is Transforming the World, Yale University.

Leamer, E.E. and R.M. Stern (1970), Quantitative International Economics, Piscataway, New Jersey, Transaction Publishers.

Lederman, D., M. Olarreaga and G. Perry (eds.) (2008), China's and India's Challenge to Latin America, Washington, D.C., World Bank.

McCombie, J.S.L. and A.P. Thirlwall (1993), Economic Growth and the Balance of Payments Constraint, London, Macmillan.

National Intelligence Council (2008), "Global Trends 2025: A Transformed World" [online] http://www.dni.gov/nic/ NIC_2025_project.html.

Naughton, B. (2007), The Chinese Economy: Transitions and Growth, Cambridge, Massachusetts, The MIT Press. 
Pavitt, K. (1984), "Sectoral patterns of technical change: towards a taxonomy and a theory", Research Policy, vol. 13, No. 6, Amsterdam, Elsevier.

Prasad, E. and R. Rajan (2006), "Modernizing China's growth paradigm", imf Policy Discussion Paper, No. 06/03, Washington, D.C., International Monetary Fund, March [online] http://www. imf.org/external/pubs/ft/pdp/2006/pdp03.pdf.

Resende, M. and H. Boff (2002), "Concentração industrial", Economia industrial: fundamentos teóricos e práticas no Brasil, D. Kupfer and L. Hasenclever (orgs.), Rio de Janeiro, Elsevier.

Rodrik, D. (2006), "What's so special about China's exports?", nber Working Paper, No. 11.947, January, Cambridge, Massachusetts, National Bureau of Economic Research [online] http://www.nber.org/papers/w11947.

Sen, S. (2010), "China in the global economy", Working Paper, No. 642, Annandale-on-Hudson, Levy Economics Institute of Bard College, December [online] http://www.levyinstitute. org/pubs/wp_642.pdf.
Spence, M. (2009), "Emerging Financial Markets after the Global Financial Crisis", PIMCO, August [online] http://www.pimco. com/LeftNav/Viewpoints/2009/Emerging+Financial+Markets+ Spence+August.htm.

Steil, B. and R.E. Litan (2006), Financial Statecraft: the Role of Financial Markets in American Foreign Policy, New Haven, Yale University Press.

Thirlwall, A.P. (2003), Economic Growth and Development with Special Reference to Developing Economies, New York, Palgrave, Macmillan.

UNCTAD (United Nations Conference on Trade and Development) (2009), Trade and Development Report, 2009 (UNCTAD/ TDR/2009), Geneva.

$\mathrm{Wu}$, J. (2005), Understanding and Interpreting Chinese Economic Reform, Mason, Ohio, Thomson.

Yufan Hao, C.X., G. Wei and L. Dittmer (comps.) (2009), Challenges to Chinese Foreign Policy: Diplomacy, Globalization and the Next World Power, Kentucky, The University Press of Kentucky. 